\title{
AC 2010-212: PROGRAM ASSESSMENT AND CONTINUOUS IMPROVEMENT PLAN FOR MASTER OF SCIENCE IN TECHNOLOGY
}

Bimal Nepal, Texas A\&M University

Jaby Mohammed, The Petroleum Institute, Abu Dhabi

Jihad Albayyari, Indiana-Purdue University

Paul Lin, Indiana University-Purdue University, Fort Wayne 


\section{Program Assessment and Continuous Improvement Plan for Master of Science in Technology}

\section{Introduction}

Undergraduate programs in Engineering and Engineering Technology are required to have an assessment and continuous improvement plan in place for obtaining accreditation from the Accreditation Board for Engineering and Technology ${ }^{1-3}$ (ABET). Although the assessment plan is very useful for both graduate and undergraduate programs, it is not very common in Engineering or Engineering Technology schools to have such plan at the Master's level. Recognizing the value of accreditation and also motivated by the University level initiatives, an assessment and continuous improvement plan has been developed for the Master of Science program in Technology (MS Tech) at Indiana University Purdue University- Fort Wayne (IPFW). The program assessment plan has already been approved by the IPFW Assessment Council and is currently being implemented.

The major goal of the MS in Technology Program ${ }^{4}$ is to prepare graduates to understand the applications of advanced concepts and knowledge of structured and analytical techniques of decision making in industry and technology. The MS Tech students study one technical track in sufficient depth to appreciate its methodologies and fundamental unresolved questions, and acquire a basis for life- long learning. Required courses for the program are established in: 1) Technology core, 2) required technical courses in the track area, 3) elective courses combining breadth of subject matter with specific study in depth, and 4) MS directed project focused on applied research. Hands-on experience of cutting edge technology and the applied research experience are essential parts of MS in Technology program. Currently, the MS program is offered in two tracks that are: 1) Information Technology/Advanced Computer Applications (ITAC), and 2) Industrial Technology/ Manufacturing (ITM).

This paper presents a comprehensive assessment and continuous improvement plan for MS in Technology program at the IPFW. In the remainder sections of the paper, we present program objectives, learning outcomes, assessment measures, and curriculum map. The assessment plan and metrics includes both direct and indirect measure. A clearly defined continuous improvement process and implementation timeline are also presented.

\section{Program Objectives}

The objective of Technology Graduate Program at IPFW is to offer a Master of Science Degree in Technology that meets the needs of regional manufacturing and service industries, research and development organizations, government, and not-for-profit organizations to prepare successful industry leaders and technical managers. The program is designed for students with both technical and non-technical backgrounds and provides the knowledge and skills required for its graduates to function effectively in a technical environment and to accept increasing responsibility in technical leadership positions. The program permits specialization in an area of modern technology applicable to each student's working environment or area of interest. 
Emphasis is placed on preparing students for technical leadership positions in business and industry, faculty positions in technology and engineering technology programs, or to continue for a PhD in Technology or a closely related field at Purdue or another university.

The following sections describe the educational objectives of each specific track.

\section{Information Technology/Advanced Computer Applications (ITAC)}

This track provides the educational experience and technical leaderships in the areas of enterprise information technology architecture, information technology security, mobile computing and networking, human-computer interaction, and strategic technology management. Students learn and apply the principles of system methodologies including analysis, design, creation, and management to contemporary problems that involve advanced computer applications and information technology systems.

\section{Industrial Technology/Manufacturing (ITM)}

The objective of the ITM track is to develop advanced leadership skills needed by technical managers and related positions in world-class industries. It widens student career potential with project management skills for organizing resources, implementing systems, increasing productivity, reducing waste and improving product quality using statistics and business research methods.

\section{Program Outcomes}

Program outcomes describe the knowledge, skills, and abilities students are expected to acquire from the program, and prepare them to achieve the program educational objectives. Measurement will be in accordance with the program assessment and continuous improvement tools given in later section.

It is intended that graduates of Master of Science in Technology program will demonstrate:

1. Ability to apply scientific thinking and structured research methods to make complex short term and long term strategic decisions making problems in industry and technology

2. Ability to apply statistical techniques to perform empirical research in industry and technology.

3. Ability to deploy existing technological systems and use emerging technologies in their functional disciplines.

4. Ability to apply specialized skills to technological problems inherent in their respective disciplines:

a. Telecommunication network and security

b. Mobile and wireless information technologies

c. Enterprise service information and architectures

d. Performance analysis and quality improvements in industry and technology

e. Design, analysis, and optimization of product and manufacturing systems

f. Management and risk mitigation of technological projects

5. Ability to perform scholarly and applied research works independently as well as in teams. 
6. Effective written, oral and presentation skills

7. Consideration of professional and ethical responsibilities in the conduct of research projects.

\section{Program Assessment and Continuous Improvement Tools}

Table 1 summarizes the assessment methods used to measure the program outcomes outlined in the earlier section. The assessment tools consist of course syllabi, student cafeteria evaluation, student's performances in the course, MS Directed Project (equivalent to thesis), exit and alumni survey and employer survey. It also clearly outlines the functional responsibilities of the instructors and MS committee including the actions needed towards the continuous improvement of the program.

\section{Assessment Measures}

The "curriculum map for M.S. in Technology" shows how the MS Tech program outcomes are achieved through the general core and specialty courses $^{5-6}$. Table 1 has illustrated a broad plan and tools used in measuring the program/course outcomes. Both direct and indirect measures are used to assess the level of accomplishment of program outcomes.

\section{Direct Measures}

The Directed Master's Project provides the first direct measure of the overall level of program outcomes achieved by the graduates of M.S. Tech program. Several MS Tech courses (e.g., IT508, TECH 646, and some specialty courses) have team projects with real life companies/organizations embedded in the course work. A formal assessment of course embedded team projects by the corresponding industry using a standardized questionnaire (which addresses the outcomes of the MS Tech program) is the second direct measure.

\section{Indirect Measures}

The indirect measures include alumni surveys and student exit surveys. These surveys include a wide range of attributes related to alumni and student satisfaction. The employer survey also provides yet another indirect measure for assessment of MS Tech program outcomes. Cafeteria evaluation is the indirect measure of the individual course outcomes.

\section{Program Assessment and Continuous Improvement Process}

The MS Tech committee oversees the overall assessment and continuous improvement process. Subcommittees are formed to analyze the specific measures of assessment. For example, Project Advisory Committees are to be formed to evaluate the students' directed projects. Each student's major advisor provides the assessment outcomes to the MS Tech committee. These outcomes are compiled and reviewed annually by the MS Tech committee to ensure continuous improvement. Another subcommittee is formed under the leadership one of the MS Tech Committee members and one faculty member from relevant academic department to conduct the alumni, exit and 
employer surveys. In other words, an MS Tech Committee member from MCET department and another MCET faculty member form a team to conduct the ITM student exit interviews, and alumni and employer surveys. The same team analyzes the data and the results are reviewed in the MS Tech committee. Student exit interviews are conducted upon graduation and alumni and employer surveys are conducted once every two years. The MS Tech committee identifies, prioritizes, and recommends necessary actions for continuous improvement to concerned academic department or faculty members.

Table 1: Summary of assessment tools their purpose and measurement frequency

\begin{tabular}{|c|c|c|c|c|c|}
\hline $\begin{array}{l}\text { Program } \\
\text { Outcomes }\end{array}$ & Tool & Purpose & Frequency & $\begin{array}{l}\text { Primary } \\
\text { Responsibility }\end{array}$ & Action \\
\hline $1-7$ & Course Syllabus & $\begin{array}{l}\text { Course schedule, } \\
\text { prerequisites, } \\
\text { learning objectives }\end{array}$ & $\begin{array}{l}\text { Each time } \\
\text { course is } \\
\text { offered }\end{array}$ & Instructor & $\begin{array}{c}\text { Academic } \\
\text { Department } \\
\text { Chair } \\
\text { and MS Tech } \\
\text { committee }\end{array}$ \\
\hline $1-7$ & $\begin{array}{c}\text { Student cafeteria } \\
\text { evaluation }\end{array}$ & $\begin{array}{c}\text { to learn student's } \\
\text { evaluation } \\
\text { of course \& change } \\
\text { the } \\
\text { course accordingly }\end{array}$ & $\begin{array}{l}\text { Each time } \\
\text { course is } \\
\text { offered }\end{array}$ & Instructor & $\begin{array}{l}\text { Instructor } \\
\text { and } \\
\text { Academic } \\
\text { Department } \\
\text { Chair }\end{array}$ \\
\hline $1,2-7$ & $\begin{array}{c}\text { Student } \\
\text { performance } \\
\text { assessments (exams, } \\
\text { quizzes, homework, } \\
\text { projects, } \\
\text { presentations } \\
\end{array}$ & $\begin{array}{l}\text { to evaluate if } \\
\text { program/course } \\
\text { outcomes are } \\
\text { fulfilled }\end{array}$ & $\begin{array}{l}\text { Each time } \\
\text { course is } \\
\text { offered }\end{array}$ & Instructor & Instructor \\
\hline $5-7$ & MS Directed Project & $\begin{array}{l}\text { To evaluate if } \\
\text { program outcomes } \\
\text { are fulfilled }\end{array}$ & $\begin{array}{l}\text { Upon } \\
\text { project } \\
\text { defense }\end{array}$ & $\begin{array}{c}\text { Project } \\
\text { Advisory } \\
\text { Committee }\end{array}$ & $\begin{array}{l}\text { Academic } \\
\text { Dept Chair } \\
\text { and } \\
\text { M.S. Tech } \\
\text { Committee }\end{array}$ \\
\hline $1-7$ & $\begin{array}{c}\text { student exit } \\
\text { interview } \\
\text { (Questionnaire) }\end{array}$ & $\begin{array}{c}\text { student's reflections } \\
\text { on } \\
\text { program }\end{array}$ & $\begin{array}{l}\text { upon } \\
\text { graduation }\end{array}$ & $\begin{array}{l}\text { MS Tech } \\
\text { Committee }\end{array}$ & $\begin{array}{c}\text { MS Tech } \\
\text { Committee } \\
\text { and } \\
\text { Academic } \\
\text { Department }\end{array}$ \\
\hline $1-7$ & $\begin{array}{l}\text { Alumni survey } \\
\text { (Questionnaire) }\end{array}$ & $\begin{array}{c}\text { Alumni perception } \\
\text { of achievement of } \\
\text { program goals }\end{array}$ & $\begin{array}{c}\text { Every } 2 \\
\text { years }\end{array}$ & $\begin{array}{l}\text { MS Tech } \\
\text { Committee }\end{array}$ & $\begin{array}{c}\text { MS Tech } \\
\text { Committee } \\
\text { and } \\
\text { Academic } \\
\text { Department } \\
\end{array}$ \\
\hline $1-4,6,7$ & $\begin{array}{c}\text { Employer survey } \\
\text { (Questionnaire) }\end{array}$ & $\begin{array}{l}\text { Employer } \\
\text { perception of } \\
\text { achievement of } \\
\text { program goals. }\end{array}$ & $\begin{array}{c}\text { Every } 2 \\
\text { years }\end{array}$ & $\begin{array}{l}\text { MS Tech } \\
\text { Committee }\end{array}$ & $\begin{array}{c}\text { MS Tech } \\
\text { Committee } \\
\text { and } \\
\text { Academic } \\
\text { Department } \\
\text { Chair }\end{array}$ \\
\hline
\end{tabular}


The analysis of each course assessment (cafeteria evaluation) is reviewed by the instructor and the corresponding chair of academic department offering the course. The review information is included in the annual assessment report. If required, the MS Tech Committee makes recommendations to the instructor and academic department chair offering the course to ensure continuous improvement.

\section{Timeline}

The MS Tech program at IPFW began during spring semester of 2007. The first batch of students has graduated in Spring 2009. Therefore, implementation of some elements of assessment plan has already begun since Fall 2008; however, the full program assessment process will not be completed until after Fall 2010. Below is a tentative timeline for M.S. Tech assessment implementation.

Fall 2008

Assessment of learning outcomes of Tech 646

Assessment of projects done in Tech 646 by client companies

Preparation of annual report of assessment activities done in Academic Year 2007-08

Spring 2009

Assessment of learning outcomes of CPET 575

Assessment of projects done in CPET 575 by client companies

Assessment of Directed Project (if applicable)

Exit Student Interview (If applicable)

Fall 2009

Discussion of Assessment Report and Recommendations

Assessment of learning outcomes of IT 508

Assessment of learning outcomes of CPETXXX

Assessment of projects by client companies

Assessment of Directed Project (if applicable)

Preparation of annual report of assessment activities done in Academic Year 2008-09

Exit Student Interview (if applicable)

Spring 2010

Assessment of learning outcomes of IT507

Assessment of learning outcomes of CPETXXX

Assessment of projects done by client companies

Assessment of Directed Project (if applicable)

Exit Student Interview (if applicable)

Fall 2010

Discussion of Assessment Report and Recommendations

Assessment of learning outcomes of Tech 571

Assessment of learning outcomes of Tech 646 
Assessment of learning outcomes of CPETXXX

Assessment of learning outcomes of CPETXXX

Assessment of projects by client companies

Assessment of Directed Project

Preparation of annual report of assessment activities done in Academic Year 2009-10

Exit Student Interview

Alumni survey

Spring 2011

Assessment of learning outcomes of every course that is offered in this semester

Assessment of projects by client companies

Assessment of Directed Project

Exit Student Interview

Employer Survey

Fall 2011

Discussion of Assessment Report and Recommendations

Assessment of learning outcomes of every course that is offered in this semester

Assessment of projects by client companies

Assessment of Directed Project

Preparation of annual report of assessment activities done in Academic Year 2010-11

Exit Student Interview

\section{Curriculum Map (M.S. Tech)}

The purpose of creating a curriculum map is to ensure that each outcome of the program is covered by the overall program. Table 2 depicts the sample curriculum map.

It specifically stipulates what is the contribution of each course and how significant that contribution is. For simplicity a 1-3 scale is used to determine how well an outcome is addressed by the course curriculum, where 1 means "Not Applicable", 2 means "Moderately Addressed" and 3 represents "Significantly Addressed". It may be worth noting that some of the courses are contributing to more than one program outcomes, likewise some of the outcomes are addressed by more than one course.

As the courses may be updated and upgraded to match the current trends and requirements of the industry, those changes might also reflect on the curriculum map. However, the curriculum map should cover all the program learning outcomes at all times. It is worth noting here that program learning outcomes are not static either. They need to be reviewed and modified on a periodic basis. 
Table 2: Curriculum map matching MS Tech courses with program outcomes

\begin{tabular}{|c|c|c|c|c|c|c|c|c|c|c|c|c|}
\hline Course Number and Title & 1 & 2 & 3 & $4 a$ & $4 b$ & 4c & $4 d$ & $4 \mathrm{e}$ & $4 \mathrm{f}$ & 5 & 6 & 7 \\
\hline $\begin{array}{l}\text { IT } 507 \\
\text { Meas \& Eval in Indus Tech }\end{array}$ & 3 & 2 & & & & & & & & 2 & 2 & \\
\hline $\begin{array}{l}\text { IT } 508 \\
\text { Qual \& Prod in Indus Tech }\end{array}$ & & & & & & & 3 & & & & 2 & \\
\hline $\begin{array}{l}\text { TECH } 646 \\
\text { Anal of Res in Indus Tech }\end{array}$ & & 3 & & & & & & & & 2 & 3 & 2 \\
\hline $\begin{array}{l}\text { CPET } 545 \\
\text { Service Orient. Architecture }\end{array}$ & & & & 3 & & & & & & & & \\
\hline $\begin{array}{l}\text { CPET 581(a) } \\
\text { Advanced Network Security }\end{array}$ & & & & & 3 & & & & & & & \\
\hline $\begin{array}{l}\text { CPET } 565 \\
\text { Mobile Computing Sys }\end{array}$ & & & & & & 3 & & & & & & \\
\hline $\begin{array}{l}\text { CPET } 575 \\
\text { Management of Tech }\end{array}$ & & & 3 & 2 & & & & & & & & \\
\hline $\begin{array}{l}\text { CPET } 581 \text { (b) } \\
\text { Wireless Sensors Networks }\end{array}$ & & & & & 2 & & & & & & & \\
\hline $\begin{array}{l}\text { TECH } 540 \\
\text { Reliability \& Maintenance }\end{array}$ & & & & & & 2 & & & & & & \\
\hline $\begin{array}{l}\text { TECH } 567 \\
\text { Tolerancing Techniques }\end{array}$ & & & & & & & 3 & & & & 2 & \\
\hline $\begin{array}{l}\text { TECH } 569 \\
\text { Simulation Modeling }\end{array}$ & & & & & & 2 & 2 & & & & & \\
\hline $\begin{array}{l}\text { TECH } 561 \\
\text { Indus Project Mgmt \& Cont }\end{array}$ & & & & & & & & & 3 & & 2 & \\
\hline $\begin{array}{l}\text { TECH } 574 \\
\text { Adv Quality Engineering } \\
\text { Tech. }\end{array}$ & & & & & & & 3 & 2 & & & & \\
\hline $\begin{array}{l}\text { XXX } 590 \\
\text { Special Topic Courses }\end{array}$ & & & & & & & & & & 2 & & 3 \\
\hline $\begin{array}{l}\text { XXX598 } \\
\text { MS Directed Projects }\end{array}$ & & & & & & & & & & 3 & & 3 \\
\hline
\end{tabular}

\section{Conclusions}

While accreditation for undergraduate programs are sort of becoming "requirements" for undergraduate engineering and engineering technology programs, it is not the case for graduate programs. As a part of its commitment to excellence, the IPFW has now a requirement for every graduate program to have an assessment plan across all of its colleges. This paper has presented a comprehensive assessment and continuous improvement plan for MS in Technology program at the IPFW. Included were program objectives, learning outcomes, assessment measures, and curriculum map. A clearly defined continuous improvement process and implementation timeline were also presented.

\section{Bibliography}

1. Technology Accreditation Commission of Accreditation Board for Engineering and Technology, Inc.,Baltimore, MD, criteria for accrediting engineering technology programs, http://abet.org/code.shtml, retrieved on Dec 17, 2009.

2. Mayes, T.S. and Bennett, J.K., 2005, ABET Best practices: results from interviews with 27 Peer institutions, Proceedings of the 2005 American Society for Engineering Education Annual Conference \& Exposition. 
3. Shryock, K. and Reed, H., 2008, ABET accreditation: best practices for assessment, Proceedings of the 2008 ASEE Gulf-Southwest Annual Conference The University of New Mexico - Albuquerque.

4. Program description, M.S. Technology Programs, Indiana University Purdue University Fort Wayne, URL: http://www.etcs.ipfw.edu/mstech/index.shtml, retrieved on Dec 17, 2009.

5. Narang, R., 2005, Course and program assessment - methodology for continuous improvement, Proceedings of the 2005 American Society for Engineering Education Annual Conference \& Exposition.

6. Ressler, S.J. and Lenox, T.A., 1996, A structured assessment system for an undergraduate civil engineering program, Proceedings of the 1996, American Society for Engineering Education Annual Conference \& Exposition. 